\title{
Contents IMIA Yearbook of Medical Informatics 2017
}

\author{
President's Statement H.-A. Park \\ President's Statement \\ Obituary J. H. van Bemmel, M. Ball, A. Hasman \\ Remembering Jana Zvárová (1943 - 2017) \\ Editorial B. Séroussi, L. F. Soualmia, J. H. Holmes \\ Transforming Data into Knowledge: How to Improve the Efficiency of Clinical Care? \\ C. U. Lehmann, H.-A. Park, E. H. Shortliffe, P. Degoulet \\ The International Academy of Health Sciences Informatics: An Academy of Excellence \\ R. Haux, A. Geissbuhler, J. Holmes, M.-C. Jaulent, S. Koch, C. A. Kulikowski, \\ C. U. Lehmann, A. T. McCray, B. Séroussi, L. F. Soualmia, J. H. van Bemmel \\ On Contributing to the Progress of Medical Informatics as Publisher \\ Keynote C. P. Friedman, J. C. Rubin, K. J. Sullivan \\ Toward an Information Infrastructure for Global Health Improvement
}

Special Section:

Learning from Experience:

Secondary Use of Patient Data

Survey C. Safran

Update on Data Reuse in Health Care

Working Group Contributions

F. J. Martin-Sanchez, V. Aguiar-Pulido, G. H. Lopez-Campos, N. Peek, L. Sacchi

Secondary Use and Analysis of Big Data Collected for Patient Care

S. M. Meystre, C. Lovis, T. Bürkle, G. Tognola, A. Budrionis, C. U. Lehmann

Clinical Data Reuse or Secondary Use: Current Status and Potential Future Progress

C. Paton, T. Karopka

The Role of Free/Libre and Open Source Software in Learning Health Systems

P. J. Scott, M. Rigby, E. Ammenwerth, J. Brender McNair, A. Georgiou, H. Hyppönen, N. de Keizer, F. Magrabi, P. Nykänen, W. T. Gude, W. Hackl

Evaluation Considerations for Secondary Uses of Clinical Data: Principles for an Evidence-based Approach to Policy and Implementation of Secondary Analysis

Synopsis D. R. Schlegel, G. Ficheur

Secondary Use of Patient Data: Review of the Literature Published in 2016

Best Paper Selection Content summaries of:

Chen J, Podchiyska T, Altman R. OrderRex: clinical order decision support and outcome predictions by data-mining electronic medical records. J Am Med Inform Assoc 2016;23:339-48

Miotto R, Li L, Kidd BA, Dudley JT. Deep Patient: An Unsupervised Representation to Predict the Future of Patients from the Electronic Health Records. Sci Rep 2016;6:26094

Prasser F, Kohlmayer F, Kuhn KA. The Importance of Context: Risk-based De-identification of Biomedical Data. Methods Inf Med 2016;55:347-55

Saez C, Zurriaga 0, Perez-Panades J, Melchor I, Robles M, Garcia-Gomez JM. Applying probabilistic temporal and multisite data quality control methods to a public health mortality registry in Spain: a systematic approach to quality control of repositories. J Am Med Inform Assoc 2016;23:1085-95 
Section 1: Health Information Management

Survey S. H. Fenton, S. Low, K. J. Abrams, K. Butler-Henderson

Health Information Management: Changing with Time

Synopsis M. Bloomrosen, E. S. Berner,

Findings from the 2017 Yearbook Section on Health Information Management

Best Paper Selection Content summaries of:

Bahous MC, Shadmi E. Health information exchange and information gaps in referrals to a pediatric emergency department. Int J Med Inform 2016;87:68-74

Esmaeilzadeh P, Sambasivan M. Health Information Exchange (HIE): A literature review, assimilation pattern and a proposed classification for a new policy approach. J Biomed Inform 2016;64:74-86

Massoudi BL, Marcial LH, Tant E, Adler-Milstein J, West SL. Using health information exchanges to calculate clinical quality measures: A study of barriers and facilitators. Healthc (Amst) 2016;4(2):104-8

Toscos T, Daley C, Heral L, Doshi R, Chen YC, Eckert GJ, Plant RL, Mirro MJ. Impact of electronic personal health record use on engagement and intermediate health outcomes among cardiac patients: a quasi-experimental study. J Am Med Inform Assoc 2016;23(1):119-28

Warner JL, Rioth MJ, Mandl KD, Mandel JC, Kreda DA, Kohane IS, Carbone D, Oreto R, Wang L, Zhu S, Yao H, Alterovitz G. SMART precision cancer medicine: a FHIR-based app to provide genomic information at the point of care. J Am Med Inform Assoc 2016;23(4):701-10

Section 2: Human Factors and Organizational Issues

Survey

Synopsis

Best Paper Selection
P. Turner, A. Kushniruk, C. Nohr

Are We There Yet? Human Factors Knowledge and Health Information Technology

- the Challenges of Implementation and Impact

S. Pelayo, R. Santos

Trends and Progress in Human Factors and Organizational Issues in 2016: Learning from Experience

Content summaries of:

Castro GM, Buczkowski L, Hafner JM. The Contribution of Sociotechnical Factors to Health Information Technology-Related Sentinel Events. Jt Comm J Qual Patient Saf 2016 Feb;42(2):70-6

Horsky J, Ramelson HZ. Development of a cognitive framework of patient record summary review in the formative phase of user-centered design. J Biomed Inform 2016 Dec;64:147-57

Kobayashi L, Gosbee JW, Merck DL. Development and Application of a Clinical Microsystem Simulation Methodology for Human Factors-Based Research of Alarm Fatigue. HERD 2016 Jan 1:1937586716673829

Percival J, McGregor C. An Evaluation of Understandability of Patient Journey Models in Mental Health. JMIR Hum Factors 2016 Jul 28;3(2):e20

Schnittker R, Schmettow M, Verhoeven F, Schraagen JM. Combining situated Cognitive Engineering with a novel testing method in a case study comparing two infusion pump interfaces. Appl Ergon 2016 Jul;55:16-26
92 
Section 3: Clinical Information Systems

Survey S. Murphy, V. Castro, K. Mandl

Grappling with the Future Use of Big Data for Translational Medicine and Clinical Care

Synopsis W. O. Hackl, T. Ganslandt

Clinical Information Systems as the Backbone of a Complex Information Logistics Process:

Findings from the Clinical Information Systems Perspective for 2016

Best Paper Selection

Content summaries of:

Anderson AE, Kerr WT, Thames A, Li T, Xiao J, Cohen MS. Electronic health record phenotyping improves detection and screening of type 2 diabetes in the general United States population: a crosssectional, unselected, retrospective study. J Biomed Inform 2016;60;162-8

Badgeley MA, Shameer K, Glocksberg BS, Tomlinson MS, Levin MA, McCormick PJ, Kasarskis A,

Reich DL, Dudley JT. EHDViz: clinical dashboard development using open-source technologies. BMJ Open 2016;6;0010579

Hadii B, Martin G, Dupuis I, Campoy E, Degoulet P. 14 Years longitudinal evaluation of clinical information systems acceptance: The HEGP case. Int J Med Inform 2016;86;20-9

Section 4: Sensor, Signal and Imaging Informatics

Survey C. Chennubhotla, L. P. Clarke, A. Fedorov, D. Foran, G. Harris, E. Helton, R. Nordstrom, F. Prior, D. Rubin, J. H. Saltz, E. Shalley, A. Sharma

An Assessment of Imaging Informatics for Precision Medicine in Cancer

Synopsis W. Hsu, S. Park, C. E. Kahn, Jr.

Sensor, Signal, and Imaging Informatics

Content summaries of:

Arnold CW, Wallace WD, Chen S, Oh A, Abtin F, Genshaft S, Binder S, Aberle D, Enzmann D.

RadPath: A web-based system for integrating and correlating radiology and pathology findings during cancer diagnosis. Acad Radiol 2016 Jan;23(1):90-100

Hravnak M, Chen L, Dubrawski A, Bose E, Clermont G, Pinsky MR. Real alerts and artifact

classification in archived multi-signal vital sign monitoring data: implications for mining big data. J Clin Monit Comput 2016 Dec;30(6):875-88

Kalpathy-Cramer J, Zhao B, Goldgof D, Gu Y, Wang X, Yang H, Tan Y, Gillies R, Napel S. A

comparison of lung nodule segmentation algorithms: methods and results from a multi-institutional study. J Digit Imaging 2016 Aug;29(4):476-87

Moss TJ, Lake DE, Calland JF, Enfield KB, Delos JB, Fairchild KD, Moorman JR. Signatures of subacute potentially catastrophic illness in the ICU: model development and validation. Crit Care Med 2016 Sep;44(9): 1639-48

Petousis P, Han SX, Aberle D, Bui AA. Prediction of lung cancer incidence on the low-dose computed tomography arm of the National Lung Screening Trial: A dynamic Bayesian network. Artif Intell Med 2016 Sep; $72: 42-55$

Springer DB, Tarassenko L, Clifford GD. Logistic regression-HSMM-based heart sound segmentation. IEEE Trans Biomed Eng 2016 Apr;63(4):822-32 
IV

Section 5: Decision Support

Survey R. A. Jenders

Advances in Clinical Decision Support: Highlights of Practice and the Literature 2015-2016

Synopsis V. Koutkias, J. Bouaud

Contributions from the 2016 Literature on Clinical Decision Support

Best Paper Selection

\section{Content summaries of:}

Lin FP, Pokorny A, Teng C, Dear R, Epstein RJ. Computational prediction of multidisciplinary team decision-making for adjuvant breast cancer drug therapies: a machine learning approach. BMC Cancer 2016 Dec 1;16(1):929

Marco-Ruiz L, Pedrinaci C, Maldonado JA, Panziera L, Chen R, Bellika JG. Publication, discovery and interoperability of Clinical Decision Support Systems: A Linked Data approach. J Biomed Inform 2016 Aug;62:243-64

McEvoy DS, Sittig DF, Hickman TT, Aaron S, Ai A, Amato M, Bauer DW, Fraser GM, Harper J, Kennemer A, Krall MA, Lehmann CU, Malhotra S, Murphy DR, O’Kelley B, Samal L, Schreiber $\mathrm{R}$, Singh $\mathrm{H}$, Thomas EJ, Vartian CV, Westmorland J, McCoy AB, Wright A. Variation in high-priority drug-drug interaction alerts across institutions and electronic health records. J Am Med Inform Assoc 2017 Mar 1;24(2):331-8

Zamborlini V, Hoekstra R, Da Silveira M, Pruski C, ten Teije A, van Harmelen F. Inferring recommendation interactions in clinical guidelines. Semantic Web 2016;7(4):421-46

Section 6: Knowledge Representation and Management

Survey S. T. Rosenbloom, R. J. Carroll, J. L. Warner, M. E. Matheny, J. C. Denny Representing Knowledge Consistently Across Health Systems

Synopsis F. Dhombres, J. Charlet Knowledge Representation and Management, It's Time to Integrate!

Best Paper Selection

\section{Content summaries of:}

Banda JM, Evans L, Vanguri RS, Tatonetti NP, Ryan PB, Shah NH. A curated and standardized adverse drug event resource to accelerate drug safety research. Sci Data 2016;3:160026

Bauer CR, Ganslandt T, Baum B, Christoph J, Engel I, Lobe M, Mate S, Staubert S, Drepper J, Prokosch HU, Winter A, Sax U. Integrated Data Repository Toolkit (IDRT). A Suite of Programs to Facilitate Health Analytics on Heterogeneous Medical Data. Methods Inf Med 2016;55(2):125-35

Greene D, NIHR BioResource, Richardson S, Turro E. Phenotype Similarity Regression for Identifying the Genetic Determinants of Rare Diseases. Am J Hum Genet 2016;98(3):490-9

Sarntivijai S, Vasant D, Jupp S, Saunders G, Bento AP, Gonzalez D, Betts J, Hasan S, Koscielny G, Dunham I, Parkinson H, Malone J. Linking rare and common disease: mapping clinical diseasephenotypes to ontologies in therapeutic target validation. J Biomed Semantics 2016;7-8 
Section 7: Consumer Health Informatics

Survey A. M. Lai, P.-Y. S. Hsueh, Y. K. Choi, R. R. Austin

Present and Future Trends in Consumer Health Informatics and Patient-Generated Health Data

Working Group Contribution

Synopsis

Best Paper Selection

Section 8: Bioinformatics and Translational Informatics

Survey

J. Vamathevan, E. Birney

A Review of Recent Advances in Translational Bioinformatics: Bridges from Biology to Medicine

Synopsis H. Dauchel, T. Lecroq

Findings from the Section on Bioinformatics and Translational Informatics

Content summaries of:

Best Paper Selection

Chen J, Rozowsky J, Galeev TR, Harmanci A, Kitchen R, Bedford J, Abyzov A, Kong Y, Regan

L, Gerstein M. A uniform survey of allele-specific binding and expression over 1000-Genomes-Project individuals. Nat Commun 2016 Apr 18;7:11101

Marbach D, Lamparter D, Quon G, Kellis M, Kutalik Z, Bergmann S. Tissue-specific regulatory circuits reveal variable modular perturbations across complex diseases. Nat Methods 2016 Apr; 13(4):366-70

Zhang D, Chen P, Zheng $\mathrm{CH}$, Xia J. Identification of ovarian cancer subtype-specific network modules and candidate drivers through an integrative genomics approach. Oncotarget 2016 Jan 26;7(4):4298-309

Zhang, J, White, NM, Schmidt, HK, Fulton, RS, Tomlinson, C, Warren, WC, Wilson, RK, Maher, CA. INTEGRATE: gene fusion discovery using whole genome and transcriptome data. Genome Res 2016;26(1):108-18 政 Identifying Personal Communication and Sentiment in Drug-Related Tweets. JMIR Public Health Surveill 60 72 175 . 
VI

Section 9: Clinical Research Informatics

Survey S. B. Johnson

Clinical Research Informatics: Supporting the Research Study Lifecycle

Working Group Contribution

Synopsis C. Daniel, R. Choquet

Clinical Research Informatics: Contributions from 2016

W. Hinton, H. Liyanage, A. McGovern, S.-T. Liaw, C. Kuziemsky, N. Munro, S. de Lusignan Measuring Quality of Healthcare Outcomes in Type 2 Diabetes from Routine Data: a Seven-nation Survey Conducted by the IMIA Primary Health Care Working Group

Best Paper Selection

Section 10: Natural Language Processing

Survey

\section{Content summaries of:}

Agarwal V, Podchiyska T, Banda JM, Goel V, Leung TI, Minty EP, Sweeney TE, Gyang E, Shah NH. Learning statistical models of phenotypes using noisy labeled training data. J Am Med Inform Assoc 2016;23(6):1166-73

Harmanci A, Gerstein M. Quantification of private information leakage from phenotype-genotype data: linking attacks. Nat Methods 2016;13(3):251-6

Pfiffner PB, Pinyol I, Natter MD, Mandl KD. C3-PRO: Connecting ResearchKit to the Health System Using i2b2 and FHIR. PloS One 2016;11(3):e0152722

Wilkinson MD, Dumontier M, Aalbersberg IJJ, Appleton G, Axton M, Baak A, Blomberg N, Boiten JW, da Silva Santos LB, Bourne PE, Bouwman J, Brookes AJ, Clark T, Crosas M, Dillo I, Dumon 0 , Edmunds S, Evelo CT, Finkers R, Gonzalez-Beltran A, Gray AJ, Groth P, Goble C, Grethe JS, Heringa J, '† Hoen PA, Hooft R, Kuhn T, Kok R, Kok J, Lusher SJ, Martone ME, Mons A, Packer AL, Persson B, Rocca-Serra P, Roos M, van Schaik R, Sansone SA, Schultes E, Sengstag T, Slater T, Strawn G, Swertz MA, Thompson M, van der Lei J, van Mulligen E, Velterop J, Waagmeester A, Wittenburg P, Wolstencroft K, Zhao J, Mons B. The FAIR Guiding Principles for scientific data management and stewardship. Sci Data 2016;3:160018

Springer DB, Tarassenko L, Clifford GD. Logistic regression-HSMM-based heart sound segmentation. IEEE Trans Biomed Eng 2016 Apr;63(4):822-32

\section{G. Gonzalez-Hernandez, A. Sarker, K. O'Connor, G. Savova}

Capturing the Patient's Perspective: a Review of Advances in Natural Language Processing of Health-Related Text

Synopsis

\section{A. Névéol, P. Zweigenbaum}

Making Sense of Big Textual Data for Health Care: Findings from the Section on Clinical Natural Language Processing

Best Paper Selection

\section{Content summaries of:}

Althoff, T, Clark K, Leskovec, J. Large-scale Analysis of Counseling Conversations: An Application of Natural Language Processing to Mental Health. Trans Assoc Comput Linguist 2016(4):463-76

Kilicoglu, H, Demner-Fushman, D. Bio-SCoRes: A Smorgasbord Architecture for Coreference Resolution in Biomedical Text. PLoS One. 2016 Mar 2;11(3):e0148538

Morid, MA, Fiszman, M, Raja, K, Jonnalagadda, SR, Del Fiol, G. Classification of clinically useful sentences in clinical evidence resources. J Biomed Inform. 2016 Apr;60:14-22

Shivade C, de Marneffe MC, Fosler-Lussier E, Lai AM. Identification, characterization, and grounding of gradable terms in clinical text. Proceedings of the 15th Workshop on Biomedical Natural Language Processing. 2016:17-26

Wu, Y, Denny, JC, Rosenbloom, ST, Miller, RA, Giuse, DA, Wang, L, Blanquicett, C, Soysal, E, Xu, J, $X u, H$. A long journey to short abbreviations: developing an open-source framework for clinical abbreviation recognition and disambiguation (CARD). J Am Med Inform Assoc 2017 Apr 1;24(e1):e79-e86 
Section 11: Public Health and

Epidemiology Informatics

Surveys

Research \& Education

History of Medical Informatics

Working Group Contribution

\author{
A. Burgun, E. Bernal-Delgado, W. Kuchinke, T. van Staa, J. Cunningham, E. Lettieri, \\ C. Mazzali, D. Oksen, F. Estupiñan, A. Barone, G. Chêne \\ Health Data for Public Health: Towards New Ways of Combining Data Sources to Support \\ Research Efforts in Europe
}

B. L. Massoudi, K. G. Chester

Public Health, Population Health, and Epidemiology Informatics: Recent Research and

Trends in the United States

Synopsis R. Thiébaut, F. Thiessard

Public Health and Epidemiology Informatics

Best Paper Selection Content summaries of:

Kite J, Foley BC, Grunseit AC, Freeman B. Please Like Me: Facebook and Public Health Communication.

PLoS One 2016;11(9)

Sharpe JD, Hopkins RS, Cook RL, Striley CW. Evaluating Google, Twitter, and Wikipedia as Tools for

Influenza Surveillance Using Bayesian Change Point Analysis: A Comparative Analysis. JMIR Public

Health Surveill 2016 20;2(2)

Tran A, Trevennec C, Lutwama J, Sserugga J, Gély M, Pittiglio C, Pinto J, Chevalier V. Development and Assessment of a Geographic Knowledge-Based Model for Mapping Suitable Areas for Riff Valley Fever Transmission in Eastern Africa. PloS Negl Trop Dis 2016;10(9)

\section{M.W. Jaspers, J. Mantas, E. Borycki, A. Hasman}

IMIA Accreditation of Biomedical and Health Informatics Education: Current State and Future Directions

\section{A. Kulikowski}

Historical Roots of International Biomedical and Health Informatics: The Road to IFIP-TC4 and IMIA through Cybernetic Medicine and the Elsinore Meetings

C. A. Kulikowski, G. Mihalas, R. A. Greenes, V. Yacubsohn, H.-A. Park

The IMIA History Working Group: Inception through the IMIA History Taskforce, and Major Events Leading Up to the 50th Anniversary of IMIA 
$\begin{array}{llr}\text { Information on IMIA } \quad \text { Welcome to IMIA } & 269\end{array}$

$\begin{array}{ll}\text { Honorary Fellows } & 272\end{array}$

IMIA Member Societies 273

$\begin{array}{ll}\text { Institutional Members } & 274\end{array}$

Addresses of IMIA Member Societies 276

Information on IMIA Regions Information on APAMI (Asia Pacific Association for Medical Informatics) 292

Information on Helina (African Region) 298

Information on IMIA-LAC (Federation of Health Societies in Latin America) 299

Information on MEAHI (Middle East Association for Health Informatics)

The 2017 MEAHI report was not submitted to the Yearbook Editors

Information on NAMI (North-American Medical Informatics) 301

Information on EFMI (European Federation For Medical Informatics) 309

Information on EFMI Working Groups 311

National Contribution C. L. Parra-Calderón, G. Gómez-Soriano, J. Galván-Romo, L. Sáez-Ayerra Innovation in Health Informatics Conference in Spain: Conclusions on the Responsibility to Use Patient Data and Big Data Methods to Improve Healthcare

$\begin{array}{lll}\text { Miscellaneous } & \text { Contributors } & 326\end{array}$

IMIA Yearbook Special Topics $\quad 327$ 